\title{
Long term correction of hyperglycaemia and progression of renal failure in insulin dependent diabetes
}

\author{
G C VIBERTI, R W BILOUS, D MACKINTOSH, J J BENDING, H KEEN
}

\begin{abstract}
The effect of long term correction of hyperglycaemia on the rate of deterioration of renal function was studied in six insulin dependent diabetics with proteinuria due to diabetic nephropathy. After a planned run in observation period of 10 to 24 months patients entered a programme of continuous subcutaneous insulin infusion for up to 24 months. Glycaemic control was promptly and significantly improved and optimal glycaemic values sustained throughout the study. Blood pressure was maintained stable. A control group of six nephropathic diabetics was studied receiving conventional insulin injection treatment but also with blood pressure control over the same period.

Despite greatly improved metabolic control in the infusion treated group no significant change in the rate of decline of glomerular filtration rate could be shown, the plasma creatinine concentrations continued to increase, and the fractional clearance of albumin and IgG rose progressively, indicating progression of glomerular damage. The conventionally treated control group behaved similarly. In a single patient receiving the continuous infusion the rate of decline of the glomerular filtration rate slowed considerably, suggesting that the response to strict diabetic control may differ in some patients.

These findings suggest that by the time glomerular function has started to fail in diabetic nephropathy the process culminating in end stage renal failure has become self perpetuating and is little influenced by the degree of metabolic control. A new definition of potential clinical diabetic nephropathy is proposed that will permit identification of patients at risk and earlier intervention by glycaemic correction in an attempt to arrest diabetic renal disease.
\end{abstract}

\section{Introduction}

The appearance of Albustix positive clinical proteinuria-that is, total urinary protein excretion exceeding about $0.5 \mathrm{~g} / 24 \mathrm{~h}-$ in insulin dependent diabetes signals the onset of clinical diabetic nephropathy, defined by a progressive decline of glomerular function to end stage renal failure. ${ }^{1-3}$ Without renal support treatment the mean survival after development of clinical proteinuria is about seven years. ${ }^{4}$ Decline of renal function during ordinary treatment with insulin is relentlessly progressive, ${ }^{3}$ though careful control of the blood pressure may slow the decline of the glomerular filtration rate in some cases. ${ }^{5}$

Strict control of glycaemic values with insulin improves morphological, histological, and hyperfunctional renal changes caused by experimentally induced diabetes in rats ${ }^{6}$ as well as

Unit for Metabolic Medicine, Guy's Hospital Medical School, London SE1 9RT

G C VIBERTI, MD, senior lecturer grade research fellow

$R$ W BILOUS, MRCP, research registrar

D MACKINTOSH, BSC, laboratory scientific officer

J J BENDING, MRCP, honorary senior registrar

H KEEN, FRCP, professor of human metabolism certain early abnormalities in the kidneys of patients with diabetes. ${ }^{7-10}$ Despite histological changes resembling those in man, animals do not develop clinical nephropathy and renal failure. ${ }^{11}$ In preliminary uncontrolled studies in patients, maintaining near normal blood glucose concentrations did not reverse clinical proteinuria ${ }^{12}$ or arrest the rise of serum creatinine values in two diabetics with renal failure ${ }^{13}$; no controlled study of the effect of long periods of greatly improved metabolic control on the progression of established diabetic nephropathy in man has been reported. The introduction of continuous subcutaneous insulin infusion made it possible to achieve and maintain near normal glycaemic values in ambulant diabetics for long periods. ${ }^{14}$ We have investigated the effect of long term (up to two years) strict glycaemic control with that treatment on the rate of deterioration of renal function in a group of insulin dependent diabetic patients with established clinical diabetic nephropathy.

\section{Patients and methods}

Six longstanding insulin dependent diabetics (table I) with clinical proteinuria and well established retinopathy were recruited for the study, which was approved by the hospital's ethical committee. In all cases the proteinuria had appeared more than 10 years after the diagnosis of diabetes and had been persistent for at least one year before the study. There was no clinical or biochemical evidence of nondiabetic renal disease; kidney biopsies in two patients showed diabetic changes only. During a non-intervention baseline period of 10 to 24 months (mean $16.8 \pm$ SD 5.9) the rate of decline of the glomerular filtration rate was established for each patient. They were then switched from conventional injection treatment to continuous subcutaneous insulin infusion and followed up for a further 12 to 24 months (mean $20 \cdot 5 \pm$ SD $4 \cdot 8$ ).

A control group of six proteinuric insulin dependent diabetics (table I) closely comparable to the study group in durations of diabetes and persistent proteinuria, blood pressure, and male preponderance were studied over similar run in periods (7-25 months; mean 16.9 \pm SD $7 \cdot 2$ ) to establish rates of decline of the glomerular filtration rate but were then continued with conventional treatment and followed up for 11.0 to 26.5 months (mean $18 \cdot 2 \pm S D 6 \cdot 2$ ).

Urinary tract infection, monitored by frequent urine culture, recurred three times in a patient allocated to receive the infusion and twice in a control patient at the beginning of the run in period. All episodes were treated with antibiotics and the patient in the infusion group (case 4) left on low dose long term antibiotic treatment, which maintained the urine sterile. All other patients had consistently negative urine cultures throughout. Antihypertensive treatment was started if systolic or diastolic pressures were 160 or $100 \mathrm{~mm} \mathrm{Hg}$ or more respectively on two consecutive visits. At least three standard assessments were made during the run in period at variable intervals (but never less than three months apart) and regularly at three and six monthly intervals (see figs 2 and 3 ) during the experimental period. During a 24 hour stay in a metabolic ward a blood glucose profile (glucose oxidase method, Analox GM 6) was constructed and the 24 hour urine output collected.

The following were measured at each visit: fasting glycosylated haemoglobin concentration, ${ }^{15}$ glomerular filtration rate (clearance of ${ }^{51} \mathrm{Cr}$ EDTA), ${ }^{16}$ plasma and urine concentrations of creatinine (determined by a reaction rate method, LKB Ultralab System 2086 Reaction Rate Analyser), $\beta_{2}$-microglobulin (Phadebas, $\beta_{2}$-Microtest, Pharmacia Diagnostics AB, Uppsala, Sweden), IgG (Immunofluor, Bio-Rad Lab, Richmond, California 94804), and albumin. ${ }^{17}$ Blood pressure was measured sitting and lying with a mercury sphygmomanometer by a trained observer at least four times a day. Plasma creatinine concen-

tration and glomerular filtration rate $\left({ }^{51} \mathrm{Cr}\right.$ EDTA) were measured in . . \section{8}


TABLE I-Clinical features of patients at entry into study

\begin{tabular}{|c|c|c|c|c|c|c|c|}
\hline Treatment group & Sex & $\begin{array}{c}\text { Mean age } \\
\text { in years } \\
\text { (range) }\end{array}$ & $\begin{array}{l}\text { Mean duration } \\
\text { of diabetes } \\
\text { in years } \\
\text { (range) }\end{array}$ & $\begin{array}{c}\text { Mean duration } \\
\text { of persistent } \\
\text { proteinuria } \\
\text { in years } \\
\text { (range) }\end{array}$ & $\begin{array}{c}\text { Mean total } \\
\text { urinary protein } \\
\text { excretion } \\
\text { (g/24 h) } \\
\text { (range) }\end{array}$ & Other complications* & $\begin{array}{c}\text { Mean blood } \\
\text { pressuret } \\
(\text { mm Hg) } \\
\text { (range) }\end{array}$ \\
\hline $\begin{array}{l}\text { Continuous insulin infusion } \\
\text { Control }\end{array}$ & $\begin{array}{l}4 \mathrm{M}, 2 \mathrm{~F} \\
5 \mathrm{M}, 1 \mathrm{~F}\end{array}$ & $\begin{array}{l}47 \cdot 0(32-58) \\
39 \cdot 8(25-57)\end{array}$ & $\begin{array}{l}21 \cdot 6(14-28) \\
19 \cdot 2(14-26)\end{array}$ & $\begin{array}{l}3 \cdot 3(1-9) \\
2 \cdot 8(1-7)\end{array}$ & $\begin{array}{l}2.4(0.61-5 \cdot 4) \\
4 \cdot 1(0.55-11 \cdot 0)\end{array}$ & $\begin{array}{l}4 \mathrm{PR}, 2 \mathrm{BR}, 6 \mathrm{PN}, 4 \mathrm{AN} \\
5 \mathrm{PR}, 1 \mathrm{BR}, 4 \mathrm{PN}, 3 \mathrm{AN}\end{array}$ & $\begin{array}{l}106 \cdot 2(93-127) \\
107 \cdot 6(97-127)\end{array}$ \\
\hline
\end{tabular}

$* \mathrm{PR}=$ Proliferative retinopathy. $\mathrm{BR}=$ Background retinopathy. $\mathrm{PN}=$ Peripheral neuropathy. $\mathrm{AN}=$ Autonomic neuropathy.

$\uparrow$ Mean blood pressure calculated as sum of diastolic pressure plus one third of pulse pressure.

all from recruitment to the study; other variables were measured on at least three successive occasions (roughly three to four months apart) before the start of the experimental period. Fractional urinary clearance of a protein was calculated by dividing its clearance by the glomerular filtration rate, corrected to $1.73 \mathrm{~m}^{2}$ body surface area.

Statistical evaluation was by analysis of covariance for comparison of slopes of regression lines and Student's $t$ test for paired and unpaired samples.

\section{Results}

There was a significant and sustained decline in glycosylated haemoglobin values after changing to continuous subcutaneous insulin infusion, the mean value falling to around $9.5 \%$ (normal range in our laboratory $5 \cdot 5-8 \cdot 5 \%$ ). No significant change was seen in the six patients who continued with conventional treatment (fig 1). Plasma glucose profiles were also greatly improved during infusional treatment. Table II shows the mean $( \pm S D)$ of paired plasma glucose determinations during the run in and experimental periods in the six patients treated by continuous infusion.

Table III shows the mean blood pressures (calculated as the sum of diastolic plus one third of pulse pressure) before and after beginning the infusion. Pressures were maintained at or below run in values. In the control group the overall mean blood pressure was $106 \cdot 7+$ SD $6 \cdot 2$ $\mathrm{mm} \mathrm{Hg}$ in the run in and $105.1 \pm 7.4 \mathrm{~mm} \mathrm{Hg}$ in the experimental period (difference not significant). Raised arterial pressures were treated equally effectively in both groups. Four patients in each group were receiving hypotensive treatment with diuretics and selective betablockers together in some case with vasodilators. Individual glomerular filtration rates with the slopes of the calculated regression of rate with time in the six patients treated by infusion are shown in fig 2 . No statistically significant difference was found between the slopes of the regression lines before or after beginning infusional treatment. In case 4 , however, the rate of decline changed from $2.4 \mathrm{ml} / \mathrm{min} / \mathrm{month}$ during conventional treatment to $0.2 \mathrm{ml} / \mathrm{min} / \mathrm{month}$ after switching to the infusion. The rapid decline during conventional treatment

TABLE II-Mean ( $\pm S D$ ) plasma glucose concentrations in six insulin dependent diabetics with clinical nephropathy before and after beginning continuous insulin infusion

\begin{tabular}{|c|c|c|c|}
\hline \multirow{2}{*}{$\begin{array}{l}\text { Case } \\
\text { No } \\
\end{array}$} & \multicolumn{2}{|c|}{ Plasma glucose (mmol/l) } & \multirow{2}{*}{$\mathrm{p}$ Value } \\
\hline & Run in period & Experimental period & \\
\hline $\begin{array}{l}1 \\
2 \\
3 \\
4 \\
5 \\
6\end{array}$ & 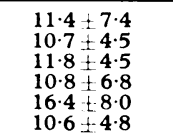 & $\begin{array}{l}7 \cdot 8 \pm 2 \cdot 8 \\
6 \cdot 5 \pm 2 \cdot 4 \\
7 \cdot 3 \pm 2 \cdot 8 \\
6 \cdot 2 \pm 2 \cdot 3 \\
6 \cdot 6 \pm 2 \cdot 5 \\
5 \cdot 6 \pm 2 \cdot 0\end{array}$ & $\begin{array}{l}<0.005 \\
<00.001 \\
<0.001 \\
<0.001 \\
<0.001 \\
<0.001\end{array}$ \\
\hline
\end{tabular}

Conversion: SI to traditional units-Glucose: $1 \mathrm{mmol} / 1 \approx 18 \mathrm{mg} / 100 \mathrm{ml}$.

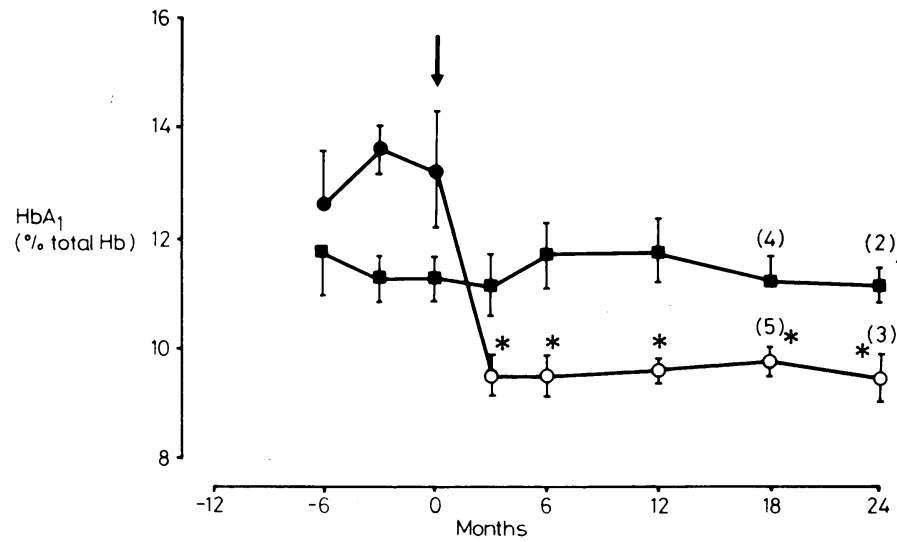

FIG 1-Mean ( \pm SEM) glycosylated haemoglobin $\left(\mathrm{HbA}_{1}\right)$ values before $(O)$ and after $(O)$ beginning continuous subcutaneous insulin infusion (arrow) in six insulin dependent diabetics with clinical nephropathy, and in six control nephropathic diabetics ( $)$ who continued with conventional insulin treatment. Numbers in parentheses indicate number of subjects when different from six.

${ }^{*} \mathrm{p}<0.05$ compared with run in (baseline) values.

TABLE IV-Mean $( \pm S E M)$ rate of decline of glomerular filtration rate in six patients treated by infusion and six controls during run in and experimental periods

\begin{tabular}{|c|c|c|c|}
\hline \multirow[t]{2}{*}{ Treatment group } & \multicolumn{2}{|c|}{$\begin{array}{l}\text { Decline in glomerular filtration rate } \\
(\mathrm{ml} / \mathrm{min} / \mathrm{month})\end{array}$} & \multirow[t]{2}{*}{ Significance } \\
\hline & Run in period & Experimental period & \\
\hline $\begin{array}{l}\text { Continuous insulin infusion } \\
\text { Control }\end{array}$ & $\begin{array}{l}1 \cdot 35 \pm 0 \cdot 31 \\
1 \cdot 24 \pm 0 \cdot 15\end{array}$ & $\begin{array}{l}0.69 \pm 0.13 \\
0.91 \pm 0.33\end{array}$ & $\begin{array}{l}\text { NS } \\
\text { NS }\end{array}$ \\
\hline Significance & NS & NS & \\
\hline
\end{tabular}

NS $=$ Not significant .

shown by this patient was largely attributable to a high glomerular filtration rate measured at the first determination.

Table IV shows the mean rate of fall in filtration rate calculated from the slopes of the regression lines during the run in and experimental periods in the six patients who changed to infusional insulin and the six who continued with conventional treatment. There were no significant differences between the two groups either during the run in period or during the experimental period. In each group the rate of decline in filtration did not differ significantly between the run in and experimental periods. In the infusional group the $95 \%$ confidence limits of the mean of the differences between the two

TABLE III-Mean ( $\pm S D$ ) of mean blood pressures (diastolic plus one third of pulse pressure) in six insulin dependent diabetics with clinical nephropathy before (only last 12 months of run in period shown) and after beginning continuous subcutaneous insulin infusion

\begin{tabular}{|c|c|c|c|c|c|c|c|c|c|c|}
\hline & \multicolumn{3}{|c|}{ Run in period (months) } & \multirow{2}{*}{$\begin{array}{c}\text { Start of } \\
\text { infusion } \\
\text { (time zero) }\end{array}$} & \multicolumn{6}{|c|}{ Experimental period (months) } \\
\hline & -12 & -6 & -3 & & 3 & 6 & 12 & $15^{*}$ & $18^{*}$ & $24 \dagger$ \\
\hline $\begin{array}{l}\text { Blood pressure }(\mathrm{mm} \mathrm{Hg}) \text { : } \\
\text { Mean } \\
\text { SD }\end{array}$ & $\begin{array}{r}106 \cdot 8 \\
13.4\end{array}$ & $\begin{array}{r}108.5 \\
14.8\end{array}$ & $\begin{array}{r}103 \cdot 6 \\
15.3\end{array}$ & $\begin{array}{r}107 \cdot 3 \\
15 \cdot 0\end{array}$ & $\begin{array}{r}109 \cdot 3 \\
12.5\end{array}$ & $\begin{array}{r}100 \cdot 7 \\
7 \cdot 3\end{array}$ & $\begin{array}{r}100 \cdot 7 \\
8 \cdot 1\end{array}$ & $\begin{array}{r}102.6 \\
2.5\end{array}$ & $\begin{array}{r}105.4 \\
9.1\end{array}$ & $\begin{array}{r}93 \cdot 3 \\
5.0\end{array}$ \\
\hline
\end{tabular}

Value in five subjects only.

+Value in three subjects only. 
treatment periods $(-0.635 \mathrm{ml} / \mathrm{min} / \mathrm{month})$ were wide, ranging from 0.24 to $-1.51 \mathrm{ml} / \mathrm{min} / \mathrm{month}$; hence there remains the possibility that a slowing of deterioration might have been missed because of small numbers.

In all but one of the patients in the infusional group the plasma creatinine concentration increased during treatment (fig 3 ); in case 4 it fluctuated in parallel with the changes in glomerular filtration rate. Mean plasma $\beta_{2}$-microglobulin concentration increased similarly and was unaffected by the switch to infusion, again with fluctuating values in case 4.

Figure 4 shows the mean fractional clearance of albumin and IgG before and after beginning infusional insulin. All patients behaved similarly and there was a progressive and statistically significan increase in the fractional clearance of these proteins during treatment.

One of the two kidney biopsies was performed in case 4 because of anomalous behaviour 16 months after changing to the infusion. It showed only classical diabetic lesions with Kimmelsteil-Wilson nodules.

\section{Discussion}

In experimentally diabetic rats correcting hyperglycaemia prevents renal histological lesions ${ }^{18}{ }^{10}$ and reverses the albuminuria and some of the morphological abnormalities once they are established. ${ }^{6}$ In diabetic patients, as in the animal model, the early abnormalities of hyperfiltration, microproteinuria, and nephromegaly are reversible by strict glycaemic control, ${ }^{7} 1020$ but no data are available in man concerning the reversibility of the early histological changes. Here, however, the resemblance ends. Features of advanced nephropathy and renal failure comparable to the clinical phase in man do not develop in diabetic rats. ${ }^{11}$

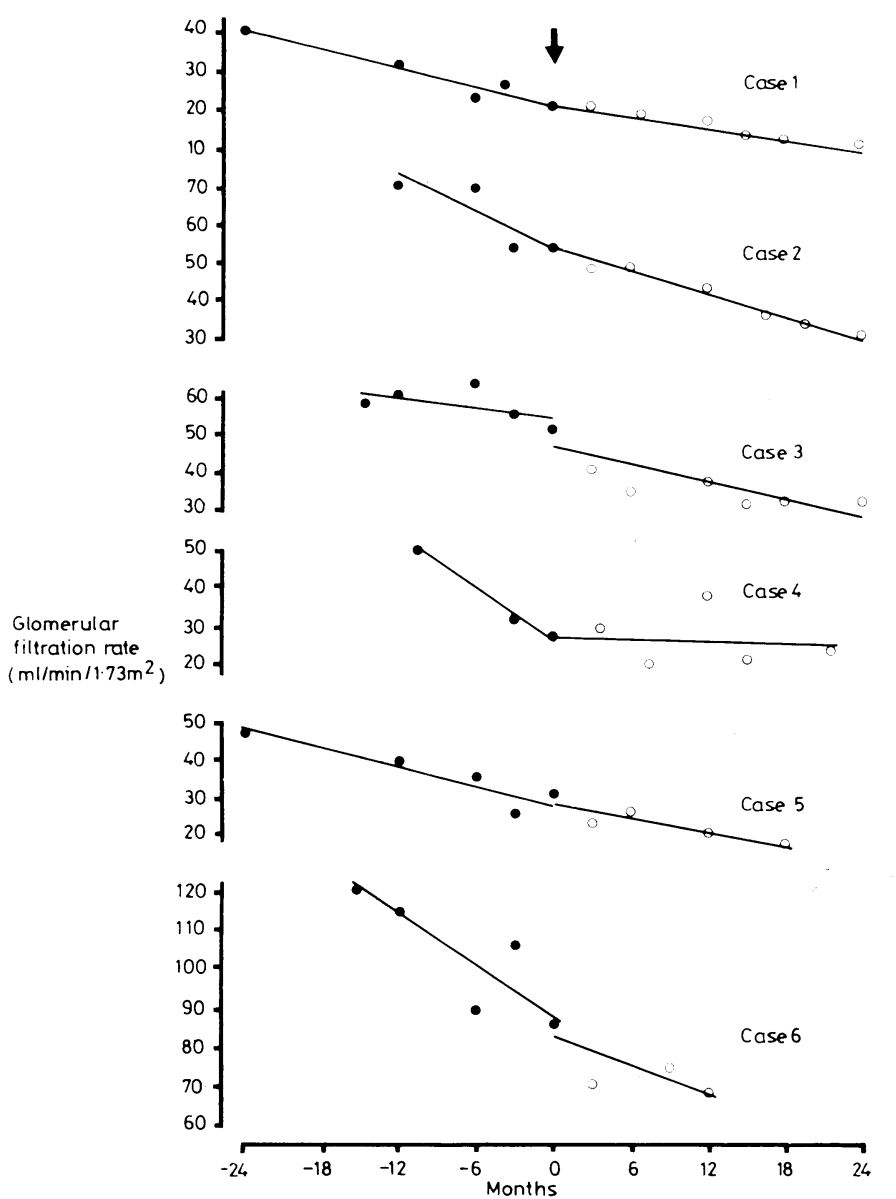

FIG 2-Individual glomerular filtration rates before (O) and after ( 0 ) beginning continuous subcutaneous insulin infusion (arrow) in six insulin dependent diabetics with clinical nephropathy. Rate of decline calculated from slopes of regression lines; individual slopes, before and after infusion, compared by analysis of covariance.

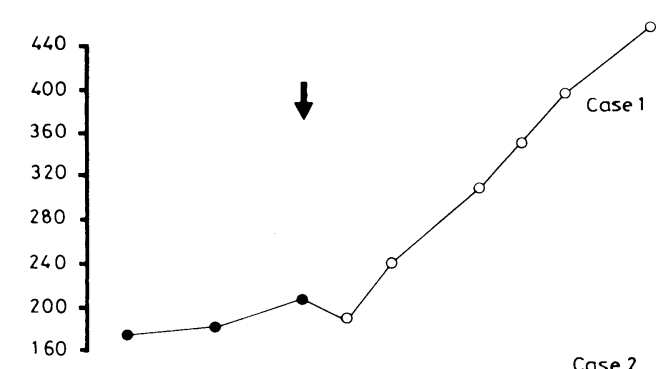



Plasma
creatinine

( $\mu \mathrm{mol} / \mathrm{l})$
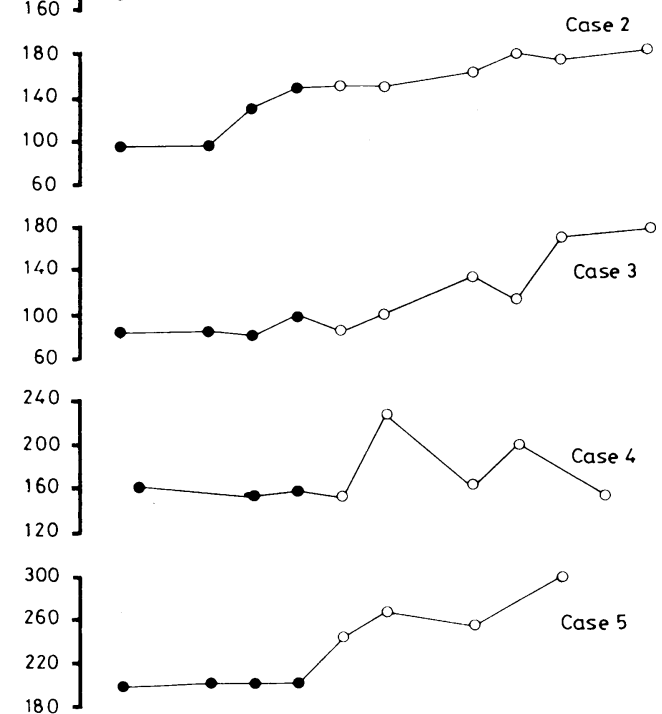

$\left.\begin{array}{c}120 \\ 80\end{array}\right]$

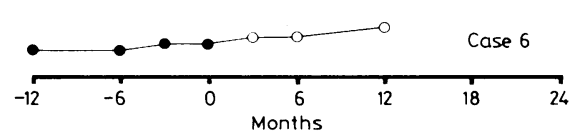

FIG 3-Individual plasma creatinine concentrations ( $\mu \mathrm{mol} / \mathrm{l})$ before ( 9 ; last 12 months of run in period shown) and after ( $O)$ beginning continuous subcutaneous insulin infusion (arrow) in six insulin dependent diabetics with clinical nephropathy.

Conversion: SI to traditional units-Creatinine: $1 \mu \mathrm{mol} / 1 \approx 0.01 \mathrm{mg} / 100 \mathrm{ml}$

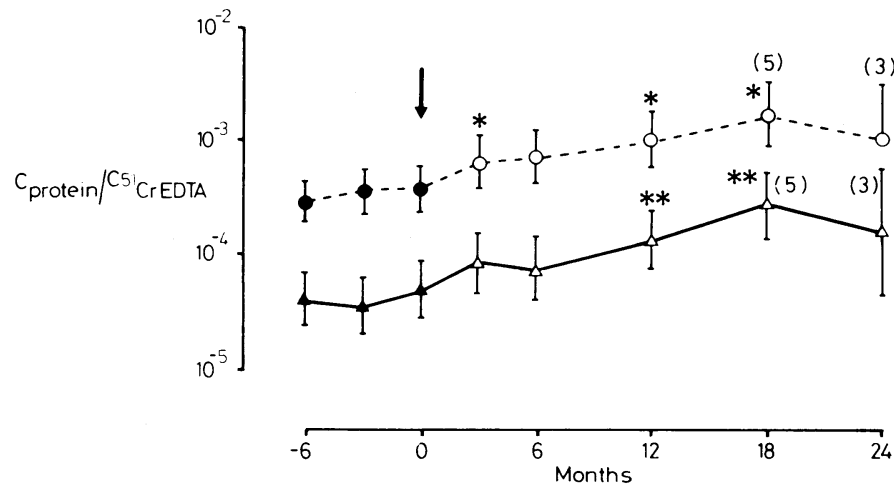

FIG 4-Mean ( \pm SEM) fractional clearance (log scale) of albumin (- - and $\operatorname{IgG}(\boldsymbol{\Delta}-\boldsymbol{\Delta})$ in six insulin dependent diabetics with clinical nephropathy before (last six months of run in period $\Delta$ ) and after $(0 \triangle$ ) beginning continuous subcutaneous insulin infusion (arrow). Numbers in parentheses as in fig 1.

$* p<0.05, * * p<0.02$ compared with run in (baseline) values.

This evidence has led to the suggestion that established clinical nephropathy in patients with diabetes may be slowed, arrested, or reversed by substantial and prolonged improvement of glycaemic control. Since raised arterial pressure also contributes to deterioration of renal function in diabetic nephropathy ${ }^{1}$ efforts were made, successfully, to maintain normal blood pressure throughout the study in both the infusion treated and control patients to reduce the confounding effect in assessing response to glycaemic control. In this small trial we were unable 
to find a statistically significant beneficial effect of metabolic correction on deterioration of renal function. From our data, however, we cannot conclude with certainty that improved control makes no difference. Glomerular filtration rate continued to fall, plasma concentrations of creatinine and $\beta_{2}$-microglobulin to rise, and the fractional clearance of albumin and IgG to increase, indicating continuing deterioration and resembling the progression in nephropathic diabetics receiving conventional insulin injection treatment. ${ }^{321}$ In some patients switched to the infusion the rate of rise in plasma creatinine concentrations appeared to accelerate, but this probably reflected the curvilinear asymptotic relation between plasma creatinine concentration and glomerular filtration rate ${ }^{321}$ in renal failure in general; it is unlikely that improved metabolic control accelerated loss of renal function.

In only one of the infusion treated patients (case 4) did improved control appear to slow considerably the rate of fall of filtration rate and rise of plasma creatinine concentration. Investigation including renal biopsy brought no non-diabetic renal disease to light and we have no ready explanation for her anomalous behaviour. Her metabolic response to infusional insulin was neither notably better nor notably worse than the other infusion treated patients. We must allow that the response of advanced nephropathy to metabolic correction of diabetes may differ from patient to patient; though continuing deterioration of renal function is the rule, exceptions may exist. The factors determining the rate of decline of glomerular filtration rate are poorly understood, but untreated urinary tract infection probably accelerates deterioration. In case 4 urinary tract infection was eradicated at the beginning of the study and was therefore unlikely to be responsible for the patient's fluctuating course.

Our failure to detect a renal response to the near normal glycaemic values induced by infusional insulin in these patients with diabetic nephropathy may be interpreted in different ways. The degree of glycaemic control we achieved with the infusion, though greatly improved, might still not have been good enough. The quality of glycaemic control was at least as good as that known to reverse the early renal changes in diabetic man and animals ${ }^{6} 89102223$ and approached what we could consider to be the optimal response of these patients to the treatment. Glycosylated haemoglobin concentrations settled slightly above the upper limit of our normal range, but in uraemic patients the increased proportion of carbamylated haemoglobin is indistinguishable from glycohaemoglobin using the microcolumn method. ${ }^{24}$ The treatment period may have been inadequate; longer periods of improved control may be necessary to affect processes that take many years to develop, even though one would expect an effect after one to two years of infusional treatment. The failure of metabolic correction to influence progressive renal deterioration is probably explained by the fact that by the time renal function is deteriorating measurably the nephropathic process has become self generating and independent of the diabetic metabolic abnormality which initiated it. When the kidney is seriously damaged further progressive deterioration of renal function loss to end stage renal failure is common to many nephropathic processes; strong experimental evidence has been presented that the compensatory hyperfiltration process in surviving nephrons after major nephron loss is ultimately self destructive. ${ }^{25}$

The important question arises whether there is a degree of diabetic renal damage beyond which this self generating process begins to operate-that is, a point of diabetic no return for the kidney, as appears to be the case in proliferative diabetic retinopathy. ${ }^{12}{ }_{26} \mathrm{~A}$ major problem in answering this question is the difficulty in quantifying renal damage in the diabetic in the phase before evident loss of renal function. At present repeated renal biopsy with its ethical and interpretative problems seems to offer the only approach; the development of less invasive, reliable methods for quantifying "total residual renal functional capacity" and monitoring the effect of treatment on it would be of great value.
Our findings strongly suggest that by the time proteinuria exceeds $0.5 \mathrm{~g} / 24 \mathrm{~h}$ (Albustix positive) the chance of affecting the deterioration of renal function by correcting the glycaemic value has passed. Clinical diabetic nephropathy is currently defined by the appearance of Albustix positive proteinuria. Recent reports ${ }^{27} 28$ indicate that by using more sensitive measures of albuminuria ${ }^{17}{ }^{29}$ diabetic patients at risk of nephropathy may be identified earlier, when renal abnormalities may still be influenced by improved diabetic control. ${ }^{8920}$ These lesser degrees of urinary albumin hyperexcretion may be reduced or normalised, at least over the short term, by metabolic correction. ${ }^{8}$ Albuminuria is a far better indicator of diabetic glomerular damage than urinary excretion of total proteins. ${ }^{20} 30$ The introduction of a new definition of potential clinical diabetic nephropathy to include diabetics with a urinary albumin excretion between 50 and $200 \mathrm{mg} / 24 \mathrm{~h}^{27}$ might therefore prove useful. This degree of microalbuminuria appears to be a marker for that proportion of insulin dependent diabetics susceptible to renal failure. It is to these patients that the most vigorous therapeutic efforts should be directed and in them that the effectiveness of glycaemic near normalisation on the development of clinical diabetic nephropathy should be tested.

We thank our diabetic patients; the sister and nurses of Peter Bishop metabolic ward; Miss A Collins and Mr A James for technical help; Dr J C Pickup for advice with insulin pumps; Dr M Maisey and the nuclear medicine department for estimating ${ }^{51} \mathrm{Cr}$ EDTA clearance; and Mr T Murrell and Dr P MacCartney for statistical advice. This study was supported by the Wellcome Trust, of which GCV is a senior research fellow. The National Medical Research Fund provided support for some of the pump studies.

\section{References}

${ }^{1}$ Mogensen CE. Progression of nephropathy in long-term diabetics with proteinuria and effect of initial anti-hypertensive treatment. Scand $\mathcal{J}$ Clin Lab Invest 1976;36:383-8.

2 Parving H-H, Smidt UM, Friisberg B, Bonnevie-Nielsen V, Anderson AR. A prospective study of glomerular filtration rate and arterial blood pressure in insulin-dependent diabetics with diabetic nephropathy. Diabetologia $1981 ; 20: 461$.

3 Viberti GC, Bilous RW, Mackintosh D, Keen H. Monitoring glomerular function in diabetic nephropathy: a prospective study. $\mathrm{Am} \mathcal{F} \mathrm{Med}$ (in press).

4 Ireland JT, Viberti GC, Watkins PJ. The kidney and the urinary tract. In: Keen H, Jarrett J, eds. Complications of diabetes. London: Edward Arnold, 1982:137-78.

${ }^{5}$ Mogensen CE. Long-term antihypertensive treatment inhibiting the progression of diabetic nephropathy. $\mathrm{Br} M e d \mathcal{F} 1982 ; 285: 685-8$.

- Mauer SM, Steffes MW, Brown DM. The kidney in diabetes. $\mathrm{Am} \mathcal{F} \mathrm{Med}$ $1981 ; 70: 603-12$.

${ }^{7}$ Mogensen CE. Renal function changes in diabetes. Diabetes 1976;25:872-9.

8 Viberti GC, Pickup JC, Jarrett RJ, Keen H. Effect of control of blood glucose on urinary excretion of albumin and $\beta_{2}$-microglobulin in insulin-dependent diabetes. $N$ Engl f Med 1979;300:638-41.

9 Viberti GC, Pickup JC, Bilous RW, Keen H, Mackintosh D. Correction of exercise-induced microalbuminuria in insulin-dependent diabetics after 3 weeks of subcutaneous insulin infusion. Diabetes $1981 ; 30: 818-23$.

10 Sandahl-Christiansen J, Gammelgaard J, Tronier B, Svendsen PAa, Parving H-H. Kidney function and size in diabetics before and during initial insulin treatment. Kidney Int 1982;21:683-8.

11 Brown DM, Andres GA, Hostetter TH, Mauer SM, Price R, Venkatachalam MA. Kidney complications. Diabetes 1982;31,suppl 1:71-81.

12 Tamborlane WV, Puklin TE, Bergman M, et al. Long-term improvement of metabolic control with the insulin pump does not reverse diabetic microangiopathy. Diabetes Care 1982;5,suppl 1:58-64

13 Pitkänen E, Hulmi S. Long-term subcutaneous insulin infusion therapy and progression of nephropathy in type 1 (insulin-dependent) diabetes. Diabetologia 1982;22:378. (Letter.)

14 Pickup JC, Keen H, Viberti GC, White MC, Kohner EM, Parson JA, Alberti KGMM. Continuous subcutaneous insulin infusion in the treatment of diabetes mellitus. Diabetes Care 1980;3:290-300.

15 Welch SG, Boucher BJ. A rapid microscale method for the measurement of haemoglobin $A_{1}(a+b+c)$. Diabetologia 1979;16:365-75.

${ }^{16}$ Chantler C, Garnett ES, Parson V, Veall N. Glomerular filtration rate measurement in man by single injection method using ${ }^{51} \mathrm{Cr}$ EDTA. Clin Sci $1969 ; 37: 169-80$.

17 Keen H, Chlouverakis C. An immunoassay method for urinary albumin at low concentrations. Lancet 1963 ;ii:913-6.

18 Rasch R. Prevention of diabetic glomerulopathy in streptozotocin diabetic 
rats by insulin treatment. Glomerular basement membrane thickness. Diabetologia 1979;16:319-24.

19 Rasch R. Prevention of diabetic glomerulopathy in streptozotocin diabetic rats by insulin treatment. The mesangial regions. Diabetologia 1979; $17: 243-8$.

20 Viberti GC, Mackintosh D, Bilous RW, Pickup JC, Keen H. Proteinuria in diabetes mellitus: role of spontaneous and experimental variation of glycaemia. Kidney Int 1982;21:714-20.

${ }^{21}$ Kult J, Lämmilein Ch, Röcken A, Heidland A. Beta-2-Mikroglobulin im serum-ein Parameter des glomerulofiltrates. Dtsch Med Wochenschr $1974 ; 99: 1686-8$.

${ }^{22}$ Lauritsen T, Frost-Larsen K, Svendsen PAa, et al. Effect of 6 months of strict metabolic control on eye and kidney function in insulin-dependent diabetics with background retinopathy. Lancet 1982 ; : 121-4.

${ }^{23}$ Mogensen CE, Anderson MJ. Increased kidney size and glomerular filtration rate in untreated juvenile diabetics: normalisation by insulin treatment. Diabetologia 1975;11:221-4.

${ }^{24}$ Flückiger R, Harmon W, Meier W, Loo S, Gabbay KH. Hemoglobin carbamylation in uremia. $N$ Engl f Med 1981 ;304:823-7.

${ }^{25}$ Hostetter TH, Rennke HG, Brenner BM. The case for intrarenal hyper- tension in the initiation and progression of diabetic and other glomerulopathies. Am F Med 1982;72:375-80.

${ }^{26}$ Lawson $\mathrm{P}$, White $M$, Rosenstock J, Kohner E. Failure of continuous subcutaneous insulin infusion as a therapeutic tool in severe forms of diabetic retinopathy. Diabetologia $1981 ; 21: 510$. (Abstract.)

27 Viberti GC, Hill RD, Jarrett RJ, Argyropoulos A, Mahmud U, Keen H. Microalbuminuria as a predictor of clinical nephropathy in insulindependent diabetes mellitus. Lancet 1982;i:1430-2.

${ }^{28}$ Parving H-H, Oxenbøll B, Svendsen PAa, Sandahl Christiansen J, Andersen AR. Early detection of patients at risk of developing diabetic nephropathy. A longitudinal study of urinary albumin excretion. Acta Endocrinol 1982;100:550-5.

29 Viberti GC, Vergani D. Detection of potentially reversible diabetic albuminuria: a 3 drop agglutination test for urinary albumin at low concentration. Diabetes $1982 ; 31: 973-5$.

30 Viberti GC, Mackintosh D, Keen H. Determinants of the penetration of proteins through the glomerular barrier in insulin-dependent diabetes mellitus. Diabetes (in press).

(Accepted 21 December 1982)

\section{SHORT REPORTS}

\section{Successful completed pregnancy in a patient maintained on home parenteral nutrition}

Total parenteral nutrition is an accepted treatment for intestinal failure resulting from conditions such as short bowel or extensive Crohn's disease. ${ }^{1}$ The effect of total parenteral nutrition on human pregnancy is not well documented. Heller ${ }^{2}$ cites hyperemesis gravidarum as an indication for short-term total parenteral nutrition but considers that lipid emulsions are contraindicated because of effects on the placenta. There have been several isolated reports of total parenteral nutrition in the third trimester, either in hospital ${ }^{34}$ or at home, ${ }^{5}$ but we do not know of any previous instance of a pregnancy maintained from conception to delivery in a patient nourished entirely by parenteral nutrition.

\section{Case report}

A 31 year old woman was referred to the nutrition unit at Hope Hospital, Salford, in June 1981 with a six year history of severe abdominal pain whenever she ate. In addition she was amenorrhoeic. Barium studies showed extensive small-bowel Crohn's disease unsuitable for surgery. Intensive medical treatment had failed to prevent frequent admissions to hospital. Severe weight loss (down to a minimum of $28 \mathrm{~kg}$ ) and weakness resulted in her being confined to a wheelchair. Total parenteral nutrition was started with considerable symptomatic relief and pronounced weight gain. She was referred to our unit for training in home parenteral nutrition.

On admission she weighed $41.8 \mathrm{~kg}$ ( $76 \%$ of ideal weight for height) Resting energy expenditure was measured by indirect calorimetry using a Beckman metabolic cart. A Broviac catheter was positioned in the superior vena cava. The patient was trained to administer her own parenteral nutrition as a nighttime infusion. Her initial daily regimen provided $14 \mathrm{~g}$ nitrogen (Synthamin, Travenol Laboratories) and 7.5 MJ (1800 kcals), half as dextrose and half as lipid emulsion (Intralipid, KabiVitrum). Trace elements and vitamins were added to the infusate.

The patient was discharged in August 1981, to continue home parenteral nutrition: her weight at discharge was $53.4 \mathrm{~kg}$ ( $97 \%$ of ideal). Iron and folate were given by mouth, and vitamin $B_{12}$ by monthly intramuscular injections. She remained free of pain provided she did not eat at all and restricted her fluid intake. She was able to lead an essentially normal life at home and care for her family unaided. The amenorrhoea persisted.

By October 1981, her weight had risen to $57 \mathrm{~kg}(104 \%$ of ideal for her height). This was thought to be due to excessive energy provision, therefore her energy intake was reduced to $4 \cdot 2 \mathrm{MJ}(1000 \mathrm{kcal})$ per day. In March 1982 , the patient and her medical advisors realised she was pregnant. Ultrasound scan confirmed a normal fetus: she had conceived about mid October 1981. The patient now weighed $58 \mathrm{~kg}$ and had a resting energy expenditure of 6 MJ (1450 kcals) per day. Energy intake was increased to $10 \mathrm{MJ}$ (2400 kcals) per day, with lipid emulsion providing about $18 \%$ of the energy. The pregnancy progressed normally, monitored by weekly assessment of maternal weight gain, ultrasound, and serial estimations of plasma oestriol, human placental lactogen, and urate concentrations (table). In the 37th week she had a normal vaginal delivery of a healthy girl, weighing $2.62 \mathrm{~kg}$. The head circumference and length were on the 50th centile for 37 weeks and the 90th
Measurements recorded during monitoring of pregnancy

\begin{tabular}{|c|c|c|c|c|}
\hline $\begin{array}{c}\text { Gestation } \\
\text { (wks)* }\end{array}$ & $\begin{array}{l}\text { Patient's } \\
\text { weight } \\
(\mathrm{kg})\end{array}$ & $\begin{array}{c}\text { Plasma } \\
\text { oestriol } \\
(\text { nmol/l) }\end{array}$ & $\begin{array}{c}\text { Plasma } \\
\text { human } \\
\text { placental } \\
\text { lactogen } \\
(\mathrm{mg} / \mathrm{l})\end{array}$ & $\begin{array}{c}\text { Plasma } \\
\text { urate } \\
(\mathrm{mmol} / \mathrm{l})\end{array}$ \\
\hline $\begin{array}{l}28 \\
30 \\
32 \\
34 \\
36 \\
36 \frac{1}{2} \\
37^{2}\end{array}$ & $\begin{array}{l}58 \\
59 \\
61 \\
62 \\
62 \cdot 5\end{array}$ & $\begin{array}{r}97 \\
113 \\
100 \\
104 \\
217 \\
226 \\
326\end{array}$ & $\begin{array}{l}5 \cdot 9 \\
7 \cdot 5 \\
6 \cdot 0 \\
5 \cdot 1 \\
5 \cdot 8\end{array}$ & $\begin{array}{l}0.25 \\
0.33\end{array}$ \\
\hline
\end{tabular}

* Gestational age assessed by fetal biparietal diameter on ultrasound scan * Gestational age assessed by fetal biparietal diameter on ultrasound scan.
Conversion: SI to traditional units-Oestriol: $1 \mathrm{nmol} / 1 \approx 28.8 \mathrm{ng} / 100 \mathrm{ml}$. Urate
$1 \mathrm{mmol} / 1 \approx 17 \mathrm{mg} / 100 \mathrm{ml}$.

centile for 40 weeks. Weight was only about the 20 th centile for 37 weeks and below the 10 th centile for 40 weeks.

Histological examination of the placenta showed it to be normal with no evidence of lipid thrombi or deposition.

\section{Comment}

Patients with Crohn's disease and severe malnutrition are often amenorrhoeic and subfertile. Though home parenteral nutrition was effective in correcting malnutrition and restoring a high quality of life in this case it did not affect the amenorrhoea. Our main problem was a total lack of information on intravenous nutritional requirements in pregnancy. We were able to measure direct the requirements for amino acids and energy, but the need for minerals, trace elements, and vitamins was more difficult to determine. Our ultimate dosage regimen was only marginally different from that given to normal patients during pregnancy.

Despite Heller's assertions ${ }^{2}$ that fat emulsions are contraindicated in pregnancy, neither patient nor baby showed ill effects from administration of lipids. Similarly, Heller's suggestion that intravenous fat emulsion may induce premature labour is not borne out by this case.

The low birth weight of the baby may be a result of inadvertent temporary reduction in energy intake during early pregnancy when an increase would have been more appropriate. Our experience has shown that home parenteral nutrition is capable of maintaining a normal pregnancy from conception to delivery. The patient described spent only four days in hospital (for assessment) throughout her pregnancy.

We thank Dr D Shreeve for referring this patient; Sister G McCannon, Dr I Holbrook, Mrs K Shipley, Dr J Shaffer, Miss C Clark, and the MRC Trauma Unit for their help in managing this case.

1 Milewski PJ, Gross E, Holbrook I, Clarke C, Turnberg LA, Irving MH. Parenteral nutrition at home in the management of intestinal failure. Br Med f 1980;280:1356-7. 